\title{
A preliminary study on the toxic potentials of shea butter effluent using Clarias gariepinus as a biological model
}

\author{
*Adewoye S.Olayinka, Adedigba A.Emmanuel and Opasola O.Afolabi \\ Department of Pure and Applied Biology LadokeAkintola University of Technology, P.M.B 4000 Ogbomoso, \\ Oyo State Nigeria
}

\begin{abstract}
This study was conducted purposely to evaluate the effects of shea butter effluent (SBE) on the freshwater inhabitant using Clarias gariepinus as a biological model. A prominent Local factory of shea butter at Tede, ATISBO Local Government was chosen because the effluent flows directly into a near-by stream that ends up at a popular Dam in the Local Government on which more than 120,000 people depend for domestic use.Static bioassay was conducted to determine the $L C_{50}$ of shea butter effluent to Clarias gariepinus. Ten fishes each were exposed to 0.05, 0.06, 0.07, 0.08, and 0.09ppt (lethal concentration) of SBE in separate water plastic bowl of $(40 \mathrm{cmX} 29 \mathrm{cmX} 28 \mathrm{~cm})$ of 60litres capacity. The lethal Concentration $\left(L C_{50}\right)$ value of SBE was 0.057ppt for 96hrs of exposure. Total mortality occurred in the concentrations of 0.08 and 0.09 ppt within 24hours of exposure period. Behavioural reactions exhibited by the fish include erratic movement, air gulping, loss of reflex, molting, barbell deformation, hemorrhage, and excessive mucus secretion in fish exposed to higher concentration of shea butter effluent.

The appreciable increase in the mean value of heavy metal, such as Manganese, Nickel, Cadmium, Zinc, Copper and Lead revealed that the increase in the concentration of shea butter effluent leads to bioaccumulation of the aforementioned heavy metals in the test organisms. The values for all the metals exceed the permissible Criteria of the national and international regulatory body. Therefore, Shea butter effluent is highly toxic to freshwater fishes, its discharged directly into water bodies, new fish farms or in areas close to aquatic environment should not be encouraged.
\end{abstract}

Keyword:Pollution, shea butter, fish, heavy metal, behavior

\section{Introduction}

In the past when industrial activities were at low levels, especially in Nigeria, many aquatic ecosystems remained largely unpolluted because pollution stress was low and easily accommodated by the natural selfpurification processes of the aquatic ecosystems. However, as a result of increased demand on aquatic resources and industrial activities, the situation has tremendously changed (Sikoki and Kolo, 1993). Owing to this, an aquatic environment has suddenly become the most polluted in most African countries including Nigeria(Adewoye et al., 2005).

In recent times, research on aquatic pollution has centered on the determination of the various contaminants and the establishment of the effects of these compounds on water quality and aquatic organisms (Sikoki and Kolo, 1993). In Nigeria, rivers are used as points for the disposal of refuse, human sewage and waste waters from kitchens, abattoirs and industries. Streams and rivers running through areas of significant human influence such as farms, cities and industrial locations are therefore prone to pollution (Egborge, 1991).

Environmental pollution has been defined as the introduction to the environment by man, substances or energy liable to cause hazards to human health, harm to living resources, as well as, ecological system; damage to structures or amenities or interference with the legitimate uses of the environment. A checklist of major toxic water pollutants (Manson, 1991) include metals such as; lead, nickel, cadmium, zinc, copper and mercury; organic compounds such as; organochlorine, pesticides, herbicides, chlorinated aliphatic hydrocarbons, solvents, straight-chain surfactants, petroleum hydrocarbons, chlorinated dibenzodioxins, polynuclear aromatics, phenols, and formaldehyde, while gases include; chlorine, ammonia etc; the anions are; cyanide, fluorides, sulphides, sulphitesetc; as well as acids and alkalis; most of which are by products of industrial, agricultural or domestic processes. The primary aim of this study was to examine the toxicologicaleffects of shea butter effluents on $C$. gariepinus.

\section{Methodology}

This experiment was carried out at the fish laboratory of the Department of Pure and Applied Biology of LadokeAkintola University of Technology, Ogbomoso. 


\section{Collection of Effluents}

The effluents used for the toxicity test were collected from the local factory of shea butter in Tede, the headquarters of ATISBO Local Government in Oke-Ogun area of Oyo state. This site was chosen based on the fact that the effluent flows into a popular Dam used by two indigenous communities with a population of about one hundred and twenty thousand.

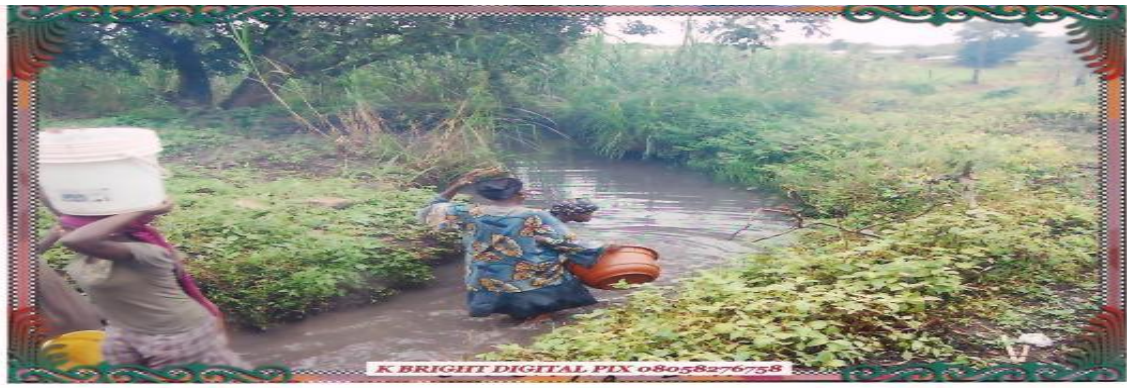

PLATE 1: Showing some Women fetching the polluted water around the factory for domestic use.

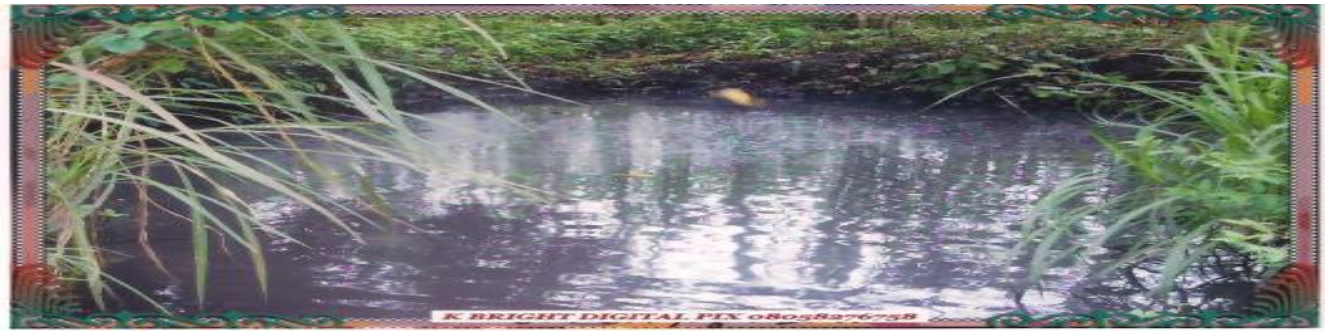

PLATE 2: Showing the impact of the shea butter effluent on the surrounding water body.

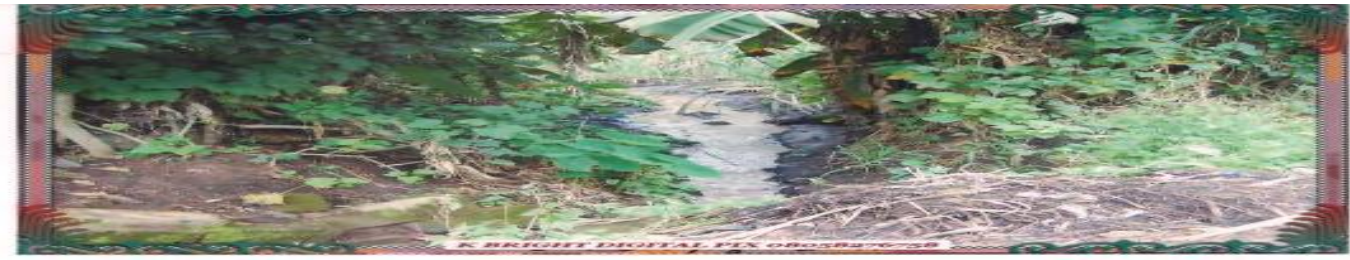

PLATE 3: Movement of shea butter effluent through a sugar cane farm plot

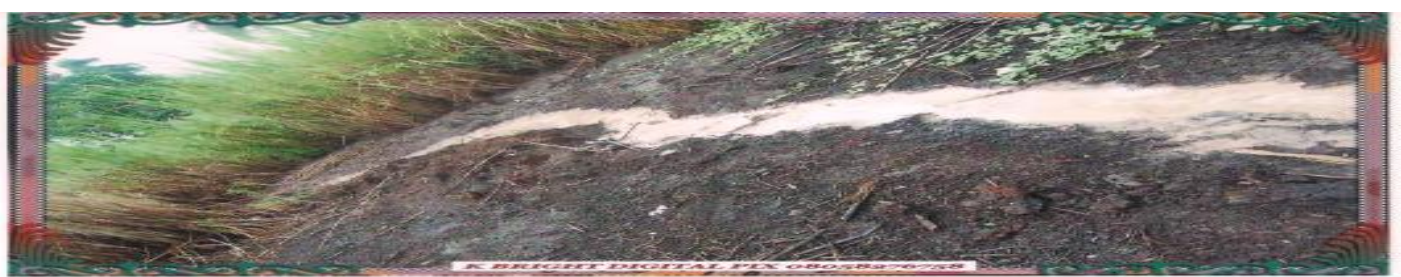

PLATE 4: Showing the effects of shea butter effluent on the surrounding plants

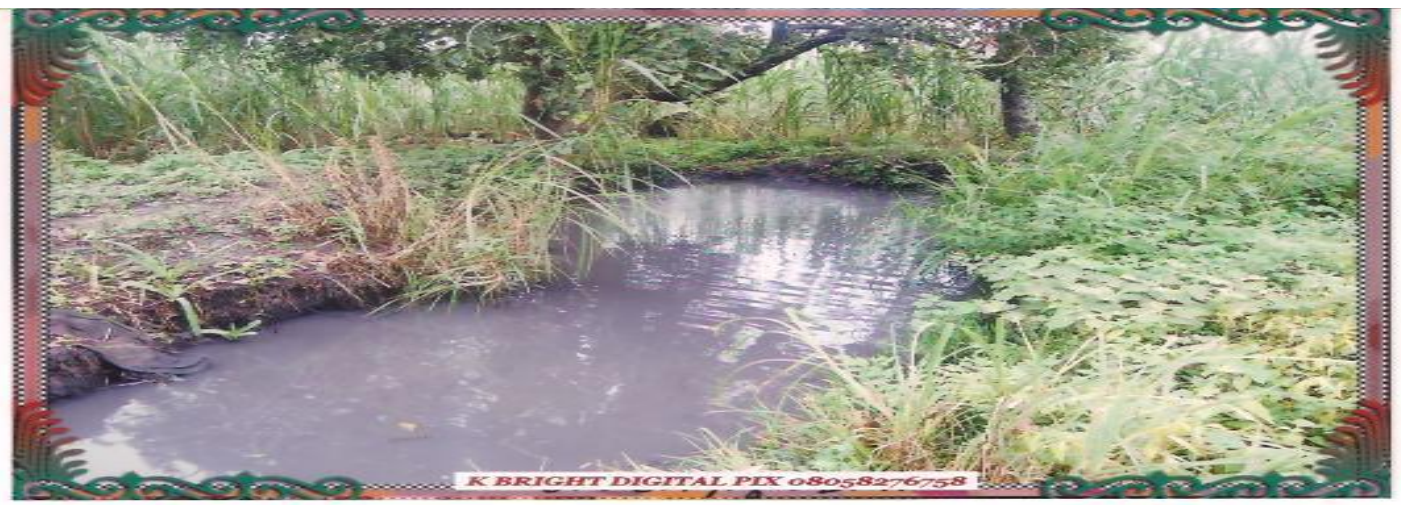

PLATE 5: Polluted water body beside the local factory 


\section{Collection and maintenance of test organism}

Post-juveniles of C.gariepinus used in this study were procured from Oyo State Ministry of Agriculture, Fishery Division, Ogbomoso. They were transported in a ventilated and aerated plastic container covered with mesh net to prevent being jumped out.

\section{Acclimatization of Fish}

The test organisms were held in $30 \mathrm{~cm} \times 30 \mathrm{~cm} \times 60 \mathrm{~cm}$ plastic container containing non-chlorinated borehole water. The borehole water was dechlorinated prior exposure to fresh air for at least three days before usage. The organisms were fed once a day during acclimatization with pelleted vital fish feed to avoid the inherited problem that could result from starvation. This lasted for fourteen days (14 days). Feeding discontinued twenty four hours prior to the commencement of the experiments.

\section{Determination of the physico-chemical parameters of the water}

The physico-chemical parameters of the water used were examined. These include temperature, dissolve oxygen and the hydrogen ion concentration $(\mathrm{pH})$. The temperature was measured with a clinical thermometer and the dissolved oxygen of the water was measured with a digital meter (Jenway 9071), while the $\mathrm{pH}$ was measured using $\mathrm{pH}$ meter model (E512).

Temperature of each concentration was determined using a mercury-in-glass thermometer. The thermometer was immersed in water at a horizontal position of about $10-15 \mathrm{~cm}$ below air-water interface. It was left in that position for 2-5 minutes for the thermometer to be stable. The thermometer was then taken out and read to obtain temperature values. In order to reduce variability, three readings were made and the mean taken as the final value.

The $\mathrm{pH}$ was determined using a $\mathrm{pH}$ meter (model E512). 50ml of water samples from those concentrations were transferred into a beaker for $\mathrm{pH}$ measurements. The $\mathrm{pH}$ meter was standardized by buffer of $\mathrm{pH} 7$ and 9 just before use, each time it was engaged in $\mathrm{pH}$ determinations (A.P.H.A, 1985).Dissolved Oxygen (DO) was determined by the method of A.P.H.A (1985).

\section{Presumptive Test}

Presumptive test also known as range-finding bioassay was carried out to determine the toxicity levels of shea butter effluents. It is a preliminary test to know the concentrations of the test solution to be use in the definitive tests for both lethal and sub lethal. The tests were conducted by diluting $400 \mathrm{ml}, 1,400 \mathrm{ml}, 10,000 \mathrm{ml}$ and 14,000 of shea butter effluents in $20,000 \mathrm{ml}$ of water (i.e $0.02,0.05,0.07,0.2,0.5$, and $0.7 \mathrm{ppt}$ ) . Ten (10) test organisms were introduced into each concentration. The result obtained was used to determine lethal and sub lethal concentrations used for this research.The experiments were conducted under bioassay procedures APHA, (1989) and Sprague (1971), which involved carefully controlled environmental conditions so as to define the response of the test organisms to the effluents.

After a range-finding test, the concentrations prepared for the experiment were $0.003,0.005,0.007,0.009$ and $0.011 \mathrm{ppt}$ for sub lethal and $0.05,0.06,0.07,0.08$ and 0.09 for lethal. The control (devoid of effluents) experiments were also set up. Renewal static bioassay was used in the sub lethal tests and static test for lethal test.

The behavioural pattern of the fish and other external changes in the body of fish were observed accordingly. Dead fish were identified by an absolute sack of movement. They were removed as soon as this was noticed and disposed. The $\mathrm{LC}_{50}$ value of the Clariasgariepinusfor 96hour was calculated using origin 8 statistical packages.

\section{Lethal Tests}

Five concentrations were used based in the result obtained in range finding test. The concentrations used were prepared arithmetically viz; $0.05,0.06,0.07,0.08$ and 0.09 . Twenty four hour starved fish were exposed to each of the concentrations of for $96 \mathrm{hrs}$.

The behaviour and general conditions of the fish were observed before, during and after the experiment. The fish were examined of mortality and considered dead when there was no response or gentle prodding. Number of dead fish were recorded and removed immediately from test medium to avoid fouling. The $96-h_{r s L C}$ was determined graphically using origin eight statistical packages.

\section{Results And Discussion}

Table 1 shows the water quality parameters of sublethal bioassays for Clarias gariepinus. The water quality parameters in the experimental concentrations did not vary significantly $(\mathrm{P}>0.05)$ from those of the control. All were within the suggested tolerance ranges. The values obtained for the physicochemical parameters 
throughout the period of sublethal test were temperature $\left(22.4-22.95^{\circ} \mathrm{C}\right)$ dissolved oxygen (7.2$\left.7.89 \mathrm{mgCaC} 03 \mathrm{mg}^{-1}\right)$ and $\mathrm{P}^{\mathrm{H}}(6.83-7.05)$

Table .1: Physicochemical properties of the various $C$. gariepinus sublethal media

\begin{tabular}{|l|l|l|l|}
\hline Concentration & $\begin{array}{l}\text { Temperature } \\
\left(0^{0} \mathrm{C}\right)\end{array}$ & $\begin{array}{l}\text { Dissolved } \\
\text { Oxygen } \\
\left.(\mathrm{mg021})^{-1}\right)\end{array}$ & $\mathrm{PH}$ \\
\hline 0.000 & $22.4 \pm 0.01$ & $7.2 \pm 0.04$ & $7.00 \pm 0.02$ \\
\hline 0.003 & $22.85 \pm 0.01$ & $7.89 \pm 0.35$ & $7.01 \pm 0.04$ \\
\hline 0.005 & $22.92 \pm 0.03$ & $7.82 \pm 0.44$ & $7.00 \pm 0.02$ \\
\hline 0.007 & $22.86 \pm 0.01$ & $7.88 \pm 0.45$ & $7.02 \pm 0.02$ \\
\hline 0.009 & $22.90 \pm 0.01$ & $7.78 \pm 0.50$ & $7.05 \pm 0.03$ \\
\hline 0.011 & $22.95 \pm 0.02$ & $7.75 \pm 0.48$ & $6.83 \pm 0.01$ \\
\hline
\end{tabular}

The result of the lethal effects of shea butter effluents on C. gariepinus at 96 hours of exposure is shown in Fig. 1 .At concentration $0.05 \mathrm{ppt}$ of shea butter effluent, $40 \%$ mortality was recorded while at concentrations $0.06,0.070 .08$ and $0.09 \mathrm{ppt}$, mortality recorded were $70,90,100$ and $100 \%$ respectively. Increase in the concentration of Shea butter effluent resulted in higher mortalities. In the control experiment, mortality was not recorded throughout the 96 hour exposure period. The median lethal concentration $\left(\mathrm{LC}_{50}\right)$ of Shea butter effluents on $C$. gariepinus was also determined graphically using origin 8 Statistical Package. The 96 hour $\mathrm{LC}_{50}$ was determined to be $0.057 \mathrm{ppt}$.

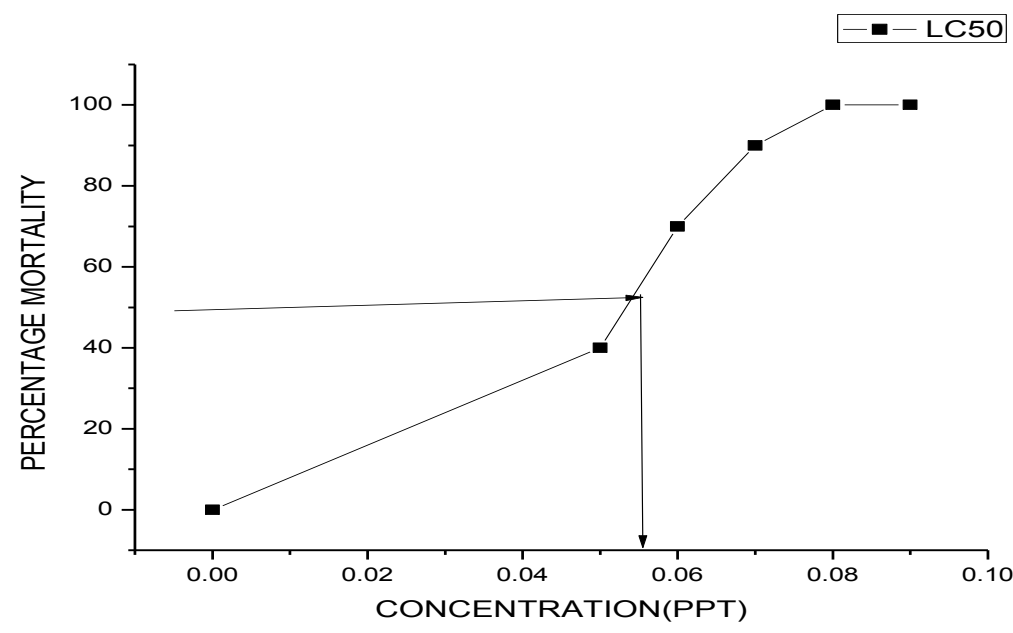

Fig.1: Lethal concentration value of the shea butter effluent

Figure 2 shows the mean Concentration of Zinc, Manganese, Iron, Lead, Nickel, Copper, Cadmium and Magnesium in the whole tissue of C. gariepinus exposed to lethal concentration of Shea butter effluents.

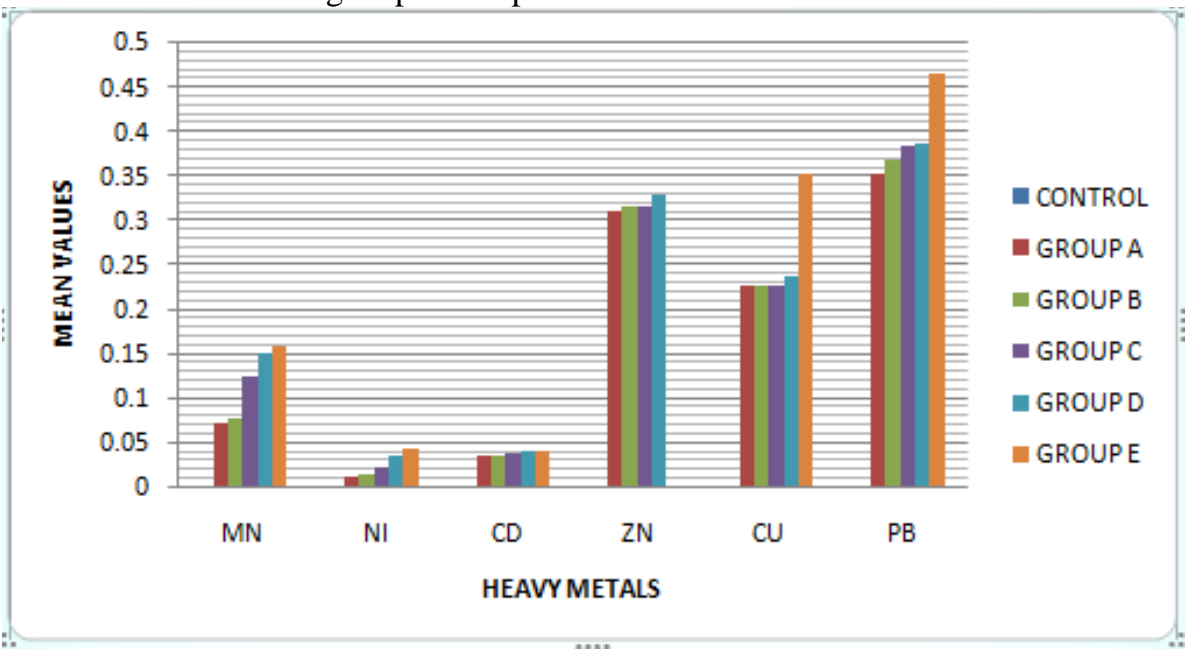

Fig.2: Heavy metal concentration in the experimental fish 


\section{Discussion}

The physico-chemical parameters of the test solution for the test organism fluctuated slightly during the bioassays but was not thought to have affected fish mortality since they were within the suggested tolerance range (Mackereth, 1963).

The hyperactivity, erratic swimming, frequent surfacing, sinking, loss of skin colouration, loss of equilibrium and gradual onset of inductivity observed in this study were in agreement with earlier reports of Okwuosa and Omoregie, (1995), Avoajah and Oti (1997) and Omoregieet al., (1990) when they exposed fish to various concentration to toxicants, Oti (2005), however opined that these behavioral responses are indications of death due to nervous disorder and insufficient oxygen supply. The excessive accumulation of mucus observed on the body surfaces and gill filaments of dead fish conformed to the findings of Annuneet al., (1994). That mucus accumulation on the body of fish results from increase in the activity of mucus cells subsequent to exposure to pollutants.

The $\mathrm{LC}_{50} ; 0.057 \mathrm{ppt}$ recorded at lethal test is less than that obtained for $C$. gariepinus when exposed to detergent effluent tests i.e. $0.032 \mathrm{mg}^{-1}$ as reported by Ikpiet al., (2003) and Adewoye et al., (2005). They however observed that at such concentrations the behavioural activities of the organisms would be disrupted and the fitness of the natural population size of an aquatic environment become relatively impaired. On the contrary, Ofojekwu and Ayuba (2006) reported a higher $\mathrm{LC}_{50} ; 123.83 \mathrm{mg}^{-1}$ for C. gariepinus exposed to root extract of DaturaInnoxia. It is however important to note that the difference in the present study from those of the earlier workers could be attributed to difference in toxicity of the effluents, fish species, sex, age and environmental factors.

The appreciable increase in the mean value of heavy metals such as Manganese, nickel, cadmium,zinc and copper as shown in figure 2 revealed that the increase in the concentration of the shea butter effluent lead to biaccumalation of the aforementioned heavy metals in the test organisms. The values for all the metals exceeded the permissible criteria of the national and international regulatory bodies (FEPA, 1991).

Bioaccumulation of metals has been reported in many fish species from Nigerian inland waters (Nwaedozie 1998). Metals enter the body of the fish via gills, skin and through the injection of contaminated food or drinking water. These metals are transported in the fish blood where ions are usually bound to proteins. The metals are thus brought into contact with the organs and tissues of the fish and consequently accumulated to a different extent in different organs and tissues. All metals taken up are not accumulated because fish have the ability to regulate their body metal concentrations to a certain extent (Kotzeet al., 1999).

Excretion of metals can occur through the gills, bile (via feaces), kidney and skin. When exposed to higher concentrations they will strive to detoxify their bodies of the pollutant as effectively as possible. It is possible that they will over compensate and thus decrease the metal concentration in the liver to a level lower than those usually detected in unpolluted conditions (Kotze et al., 1999).

\section{Conclusion And Recommendation}

Investigations into the effects of Shea butter effluent revealed that it is toxic to aquatic organisms. Therefore, indiscriminate discharge of shea butter effluent into water bodies should be vehemently discouraged and the recipient streams and rivers/dams should be maintained to conform to the international standard for water quality.

\section{References}

[1]. Adewoye .O., O.O., Owolabi, O.D and Omotosho J.S. (2005): Toxicity ofCassava wastewater effluent to African catfish: Clariasgariepnus.Ethiop. J.Sci, 28(2) pp. 189-194

[2]. Annume, P.A., Ebele, S.O. and Oladimeji, A.A. (1994): Acute toxicity of Cadmium to Clariasgariepinus (Teugels) and Orechromisniloticus(Trewavas). Journal of Environmental Science and Health.29(7); 1357.

[3]. APHA (1985): Standard methods for the examination of water and wastewater.AmericanPublic Health Association $16^{\text {th }}$ edition, Washington DC.1268pp.

[4]. APHA (1989): Standard methods for examination of water and wastewater(17 ${ }^{\text {th }}$ Edition): prepared and published jointly by: American PublicHealth Association (APHA); American Water Works Association(AWWA) and Water Pollution Control Federation (WPCF).

[5]. Avoajah, D.A and Oti, E.E (1997): Effect of sublethal concentration of some Pesticides on thegrowth and survival of the fingerlings of the African Freshwater Catfish: - HeteroclariasHybrid Fingerlings) Nigeria Journal of Biotechnology 8; 40 - 45.

[6]. Egborge, A.B.M (1991): Industrialization and heavy metal pollution in WarriRiver.32 ${ }^{\text {nd }}$ Inagural lecture, University of Benin city, Nigeria. $12^{\text {th }}$ April, 1991, 32pp.

[7]. FEPA (1991): Federal Environmental Profection Agency: Guidelines and standards for environmental pollution in Nigeria.

[8]. Ikpi G.U., Ogunyemi O.O., Offem B. (2003): Toxicity of industrial effluent on Oreochroomisniloticusfingerlings in Ado-Ekiti, Nigeria 1 (1) $177-182$ :

[9]. Kotze, P. Du Preez H.H., and VanVuren J.H.J. (1999): Bioaccumulation of copper and zinc in OreochromismossambicusandClarias gariepinus from the Olifants River, Mpumalanga, South Africa. Water SA 25(1) 99-110.

[10]. Mackereth F.J.H. (1963): Some Methods of water analysis for limnologists. Freshwater Biological Association Scientific Publication No 21, 70pp

[11]. Manson, C.F. (1991): The biology of fresh water pollution John Wiley and sons; New York, $28-35 \mathrm{pp}$ 
[12]. Nwaedozie, J.M. (1998): The determination of heavy metal pollutions in fish samples from river Kaduna. J. Chem. Soc. Nig. 23, 21-23pp.

[13]. Ofojekwu P.C. and Ayuba V.O (2005): Evaluation of toxicity effect of Daturainnoxiarootextract to Clarias gariepinus fingerlings. Proceeding of the 16th annual conference of the fisheries society of Nigeria (FISON) Maiduguri.212-215pp.

[14]. Okwuosa V.A and Omoregie E. (1995): Acute toxicity of Alikylbenzenesulphonate. Aquaculture Res. 26: 755 - 758pp.

[15]. Omoregie, E, Ufodike, E.B.C and Keke, I.R. (1990): Tissues chemistry of O. niloticus exposed to sublethal concentrations of Gammalin 20 and Actellic25EC. J. of Aquatic Science, 5: $33-36$.

[16]. Oti E.E (2005): Acute toxicity of gammalin 20 to Chrysichthysnigrodigitatus (Lacepede). Proceeding of the $16^{\text {th }}$ annual conference of the fisheries society of Nigeria (FISON) Maiduguri.175-179pp.

[17]. Sikoki, F.D and Kolo R.J (1993): Perspective in water pollution and their implications forconservation of aquatic resources. Proceeding of the national conference on conservation of aquatic resources.Organized by National advisory committee on conservation of renewable resources.Incooperation with Federal of Fisheries, Abuja and Nigerian Institute for oceanography and marine research, Lagos, $184-192$.

[18]. Sprague, J.B. (1971): Measurement of pollutant toxicity to fish 111 sublethaleffects and safeconcentrationsWater Res. Pergamon press $5.245-266$ 